\title{
Effects of nitrogen enrichment on biomass allocation, growth, and leaf morphology of the seagrass Thalassia testudinum
}

\author{
Kun-Seop Lee, Kenneth H. Dunton* \\ The University of Texas at Austin, Marine Science Institute, 750 Channel View Drive, Port Aransas, Texas 78373, USA
}

\begin{abstract}
The effects of sediment ammonium $\left(\mathrm{NH}_{4}{ }^{+}\right)$enrichment on biomass allocation, growth, and leaf morphology of the seagrass Thalassia testudinum in Corpus Christi Bay (CCB) and lower Laguna Madre (LLM), Texas, were examined from May to October 1997. Prior studies had shown that shoot height and leaf biomass at CCB were significantly higher than those at LLM, and ambient sediment $\mathrm{NH}_{4}{ }^{+}$concentrations in CCB (ca $100 \mu \mathrm{M}$ ) were significantly higher than those in LLM (ca $30 \mu \mathrm{M}$ ). It was hypothesized that the differences in plant morphology and biomass between the 2 areas could be related to differences in sediment nitrogen levels between 2 sites. To test this hypothesis, we conducted an in situ fertilization experiment at both sites over a 6 mo period. Results of this experiment revealed that seagrass growth, biomass and leaf size significantly increased as a result of sediment $\mathrm{NH}_{4}{ }^{+}$enrichment at LLM, but had little effect on plant density, biomass and leaf morphology at CCB. In unfertilized plots, average leaf production rate $\left(7.4 \mathrm{~g}\right.$ dry $\left.w \mathrm{~m}^{-2} \mathrm{~d}^{-1}\right)$ and shoot height $(43.3 \mathrm{~cm})$ at CCB were significantly higher than those at $\operatorname{LLM}\left(2.5 \mathrm{~g}\right.$ dry $w t \mathrm{~m}^{-2} \mathrm{~d}^{-1}$ and $18.8 \mathrm{~cm}$, respectively). After fertilization, leaf production rates and leaf size at LLM increased to reach equivalent levels of the CCB site. Leaf biomass at LLM increased significantly as a result of sediment $\mathrm{NH}_{4}{ }^{+}$enrichment, but there was little change in below-ground biomass. The below-to above-ground biomass ratio at LLM (4.7) was about 3-fold higher than that at CCB (1.6) in unfertilized plots, but decreased significantly at LLM with sediment $\mathrm{NH}_{4}^{+}$enrichment, while the ratio at $\mathrm{CCB}$ remained unchanged. We conclude, based on seagrass growth responses to increases in sediment $\mathrm{NH}_{4}{ }^{+}$, that sediment nitrogen availability at LLM limits seagrass productivity. $T$. testudinum responded to limited nitrogen conditions by increasing below- to above-ground biomass ratios. An ambient sediment $\mathrm{NH}_{4}{ }^{+}$level of about $100 \mu \mathrm{M}$ was considered to be the threshold concentration for nitrogen limitation of seagrass growth.
\end{abstract}

KEY WORDS: Seagrass · Sediment ammonium - Thalassia testudinum - Nitrogen enrichment Nitrogen limitation - Growth - Biomass allocation

\section{INTRODUCTION}

Seagrasses are important primary producers in coastal and estuarine ecosystems. As autotrophs, seagrasses require light, inorganic carbon sources, and inorganic nutrients (e.g. nitrogen and phosphate). Because of their high production rates, e.g. $1000 \mathrm{~g}$ dry wt $\mathrm{m}^{-2} \mathrm{yr}^{-1}$ (McRoy \& McMillan 1977), seagrass beds may assimilate and sequester large amounts of inorganic nitrogen $(\mathrm{N})$ and phosphorus $(\mathrm{P})$, dominating estuarine nutrient cycling (Kenworthy et al. 1982,

\footnotetext{
•Corresponding author. E-mail: dunton@utmsi.utexas.edu
}

Romero et al. 1994). Thus, nutrient availability may play a significant role in regulating seagrass production in shallow and clear areas where light is plentiful. Fertilization studies have shown that the addition of $N$ or $P$ can stimulate seagrass growth resulting in increased biomass (Orth 1977, Harlin \& Thorne-Miller 1981, Iizumi et al. 1982, Dennison et al. 1987, Short et al. 1990, Pérez et al. 1991, Murray et al. 1992, Williams \& Ruckelshaus 1993), suggesting nutrient limitation for plant growth.

Seagrasses have access to inorganic- $\mathrm{N}$ sources in both the sediment and the water column (Iizumi \& Hattori 1982, Thursby \& Harlin 1982, Short \& McRoy 1984, Stapel et al. 1996, Stapel \& Hemminga 1997, Terrados 
\& Williams 1997, Lee \& Dunton 1999b). N enrichment of the water column can lead to decreased underwater light availability as a result of epiphyte growth and phytoplankton blooms that can lead to seagrass decline (Orth \& Moore 1983, Silberstein et al. 1986, Giesen et al. 1990, Tomasko \& Lapointe 1991). In addition, Burkholder et al. $(1992,1994)$ demonstrated that water column nitrate $\left(\mathrm{NO}_{3}{ }^{-}\right)$enrichment caused death of Zostera marina through a direct physiological effect unrelated to algal light attenuation. In most cases, however, sediment $\mathrm{N}$ enrichment enhanced seagrass growth, and no harmful effects have been reported (Bulthuis \& Woelkerling 1981, Agawin et al. 1996, Alcoverro et al. 1997, Udy \& Dennison 1997). Therefore, although a high $\mathrm{N}$ requirement has been demonstrated for seagrass growth, the plant responses to increased $\mathrm{N}$ availability may vary depending on the $\mathrm{N}$ sources.

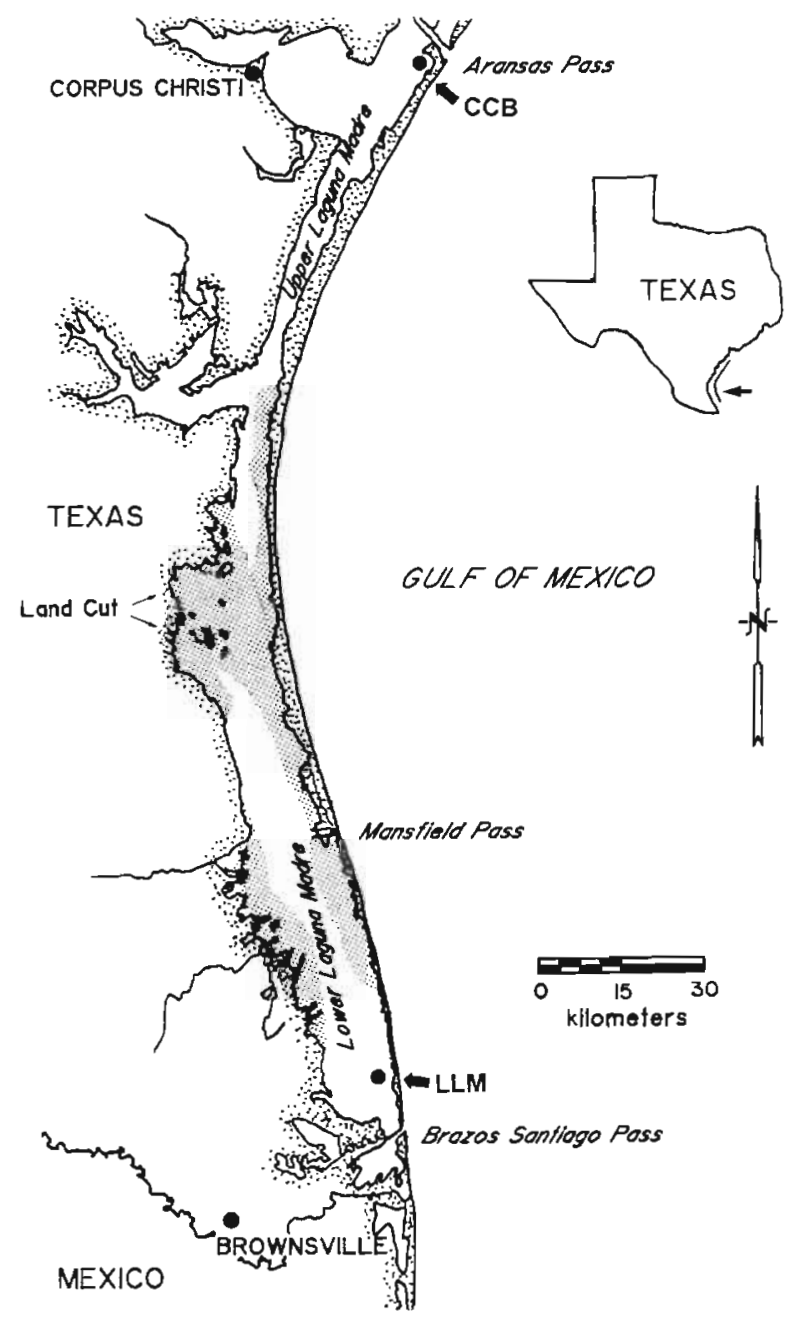

Fig. 1. Study sites in Corpus Christi Bay (CCB) and lower Laguna Madre (LLM), Texas, USA. Stippled areas represent wind-tidal flats, which are periodically flooded
Due to the high concentration of $\mathrm{NH}_{4}{ }^{+}$in pore waters relative to the overlying water column, seagrasses obtain a large fraction of their $\mathrm{N}$ from the sediment via root tissues (Iizumi \& Hattori 1982, Short \& McRoy 1984, Zimmerman et al. 1987, Lee \& Dunton 1999b). Sediment $\mathrm{NH}_{4}{ }^{+}$is the most abundant source of $\mathrm{N}$ in seagrass beds (Agawin et al. 1996, Dunton 1996, Terrados \& Williams 1997) and consequently plays an important role in regulation of seagrass growth. The concentration of sediment $\mathrm{NH}_{4}{ }^{+}$is highly variable, ranging from less than $20 \mu \mathrm{M}$ (Bulthuis et al. 1992 , Agawin et al. 1996, Udy \& Dennison 1997) to well over $100 \mu \mathrm{M}$ (Bulthuis \& Woelkerling 1981, lizumi et al. 1982, Fourqurean et al. 1992, Czerny \& Dunton 1995, Dunton 1996). Most sediment $\mathrm{NH}_{4}{ }^{+}$is supplied by remineralization processes in sediments (Jørgensen 1977, 1982, Hines \& Lyons 1982, Boon et al. 1986, Holmer \& Nielsen 1997). In situ sediment $\mathrm{NH}_{4}{ }^{+}$concentrations represent a balance between $\mathrm{NH}_{4}{ }^{+}$production and consumption. Thus, in most cases, existence of $\mathrm{N}$ limitation in each seagrass bed probably depends on in situ sediment $\mathrm{NH}_{4}{ }^{+}$level, and the sediment $\mathrm{NH}_{4}{ }^{+}$concentration may be used as a indicator of the $\mathrm{N}$ status for seagrass growth.

Seagrasses living under varying conditions of $\mathrm{N}$ availability may respond differently to sediment $N$ enrichment, and $\mathrm{N}$ limitation can be predicted from plant responses. The present study focused on plant responses to sediment $\mathrm{N}$ fertilization in 2 distinct Thalassia testudinum populations in Texas: Corpus Christi Bay (CCB) and lower Laguna Madre (LLM). Previous studies demonstrated that plant height and leaf biomass in CCB were significantly higher than in the LLM (Lee \& Dunton 1996, Herzka \& Dunton 1997, Kaldy 1997). These differences were hypothesized to result from measured differences in the availability of pore water $\mathrm{NH}_{4}{ }^{+}$in the 2 areas. The present study tested the hypothesis that while $N$ availability at LLM is limiting for plant growth, the $\mathrm{N}$ requirements of $T$, testudinum at $\mathrm{CCB}$ are adequately met. Changes in productivity, biomass allocation, and leaf morphology were evaluated in response to in situ sediment $\mathrm{NH}_{4}{ }^{+}$enrichment at the 2 sites. Pore water $\mathrm{NH}_{4}{ }^{+}$, nitrate + nitrite $\left(\mathrm{NO}_{3}{ }^{-}+\right.$ $\left.\mathrm{NO}_{2}{ }^{-}\right)$and phosphate $\left(\mathrm{PO}_{4}{ }^{3-}\right)$ levels were monitored to assess sediment nutrient availability for $T$. testudinum growth.

\section{MATERIALS AND METHODS}

Study site. The study was conducted in monotypic meadows of Thalassia testudinum in CCB $\left(27^{\circ} 49^{\prime} \mathrm{N}\right.$, $\left.97^{\circ} 07^{\prime} \mathrm{W}\right)$ and LLM $\left(26^{\circ} 09^{\prime} \mathrm{N}, 97^{\circ} 12^{\prime} \mathrm{W}\right)$, Texas, USA. The study sites are located at similar water depth (1.2 $\mathrm{m} ;$ Fig. 1), and have been the focus of several 
recent studies on south Texas seagrasses (Dunton 1990, 1994, Quammen \& Onuf 1993, Czerny \& Dunton 1995, Lee \& Dunton 1996, 1997, Herzka \& Dunton 1997, 1998, Kaldy 1997). The CCB population is located on the eastern side of CCB and is characterized by high pore water $\mathrm{NH}_{4}{ }^{+}$concentration (ca $100 \mu \mathrm{M}$ ) and high sand content in the sediment (Table 1). In contrast, the sediments at the LLM site, located $200 \mathrm{~km}$ to the south, have lower pore water $\mathrm{NH}_{4}{ }^{+}$concentration (ca $30 \mu \mathrm{M}$ ) and sand content. T. testudinum plants growing at $\mathrm{CCB}$ are much taller and have higher leaf biomass. Water column $\mathrm{NH}_{4}{ }^{+}$and $\mathrm{NO}_{3}{ }^{-}+\mathrm{NO}_{2}{ }^{-}$at both ferent. Underwater photosynthetically active radiation (PAR) was significantly higher at LLM than CCB (Table 1). The T. testudinum bed in LLM represents a relatively young population which replaced Syringodium filiforme in the 1970 s and 1980s (Quammen \& Onuf 1993).

Sediment $\mathrm{NH}_{4}{ }^{+}$enrichment. At each site, 6 experimental plots $(1.0 \times 1.0 \mathrm{~m})$ were established in a homogeneous Thalassia testudinum meadow. Three served as controls and 3 were enriched with ammonium sulfate (21-0-0, Esco Corp., Dallas, TX). The fertilizer was wrapped in several layers of cheesecloth and in each plot, 25 packets consisting of $20 \mathrm{~g}$ of fertilizer were buried at $20 \mathrm{~cm}$ intervals in a horizontal grid and at about $10 \mathrm{~cm}$ sediment depth. The amount of $\mathrm{N}$ applied to each enriched plot was $105 \mathrm{~g} \mathrm{~N} \mathrm{~m}^{-2}$ based on manufacturer's nominal values. Agawin et al. (1996) compared sediment disturbed and undisturbed sites to sites were about $1 \mu \mathrm{M}$ and were not significantly dif-

assess the effects of experimental sediment disturbance on seagrass. No significant sediment disturbance effects were found, and we presume the same for our study sites. The rhizome connections at the perimeter of each plot were cut to a sediment depth of about $30 \mathrm{~cm}$ to physiologically separate plants located within and outside the plots. The effects of physical damages as a result of rhizome cutting are very limited on plants within plots of this size and restricted to plants growing at the edge of the plots. In addition, rhizome cutting effects are also offset by cutting the rhizome connections at control plots. Ammonium fertilizer was added in early May 1997; plant and sediment samples were collected monthly from May to October from both control and treatment plots.

Sediment nutrient analyses. On each sampling date, 3 replicate sediment samples were collected randomly from each plot to a depth of ca $13 \mathrm{~cm}$ with a $60 \mathrm{ml}$ syringe corer. Samples were placed on ice and frozen pending lab analyses. Sediment pore water was obtained by centrifugation ( $5000 \times g$ for $15 \mathrm{~min}$ ) and used for determination of pore water $\mathrm{NH}_{4}{ }^{+}, \mathrm{NO}_{3}{ }^{-}+$ $\mathrm{NO}_{2}{ }^{-}$and $\mathrm{PO}_{4}{ }^{3-}$ concentrations. Concentrations of $\mathrm{NH}_{4}{ }^{+}$and $\mathrm{PO}_{4}{ }^{3-}$ were determined using standard colorimetric techniques following the methods of Parsons et al. (1984) after dilution (1:5; v/v) with low nutrient sea water collected offshore in the Gulf of Mexico. Concentrations of $\mathrm{NO}_{3}{ }^{-}+\mathrm{NO}_{2}{ }^{-}$were determined colorimetrically after running through a column containing copper coated cadmium which reduces $\mathrm{NO}_{3}{ }^{-}$to $\mathrm{NO}_{2}^{-}$(Parsons et al. 1984).

Biological measurements. Measurements of shoot density, biomass,

Table 1. Biological, physical and chemical characteristics of study sites in Corpus Christi Bay (CCB) and lower Laguna Madre (LLM), Texas. Values are from a long-term data set collected since 1990 (Herzka \& Dunton 1997, 1998, Lee \& Dunton 1997, Kaldy 1998, Dunton unpubl data). $\mathrm{p}<0.05 ; \cdots p<0.01 ; \cdots p<$ 0.001 : significant differences between the 2 study sites based on $t$-tests. Mean \pm SE (sample size)

\begin{tabular}{|c|c|c|}
\hline \multirow[t]{2}{*}{ Parameter } & \multicolumn{2}{|c|}{ Site } \\
\hline & CCB & LLM \\
\hline \multicolumn{3}{|l|}{ Sediment } \\
\hline Pore water ammonium $(\mu \mathrm{M})$ & $115.08 \pm 11.12(51)$ & $24.27 \pm 2.42(19)^{\cdots}$ \\
\hline Sand content $(\%)$ & $91.19 \pm 0.47(58)$ & $71.44 \pm 1.27(35) \cdots$ \\
\hline Clay + silt $(\%)$ & $8.81 \pm 0.47(58)$ & $28.60 \pm 1.26(35)^{\cdots}$ \\
\hline \multicolumn{3}{|l|}{ Water column } \\
\hline Ammonium & $1.16 \pm 0.06(58)$ & $1.22 \pm 0.08(38)$ \\
\hline Nitrate + nitrite & $0.84 \pm 0.05(58)$ & $0.84 \pm 0.06(38)$ \\
\hline \multicolumn{3}{|l|}{ Thalassia testudinum } \\
\hline Height $(\mathrm{cm})$ & $41.42 \pm 0.63(149)$ & $18.64 \pm 0.28(196)^{\cdots}$ \\
\hline Leaf biomass ( $\mathrm{g}$ dry wt $\mathrm{m}^{-2}$ ) & $227.76 \pm 24.85(15)$ & $159.42 \pm 11.32(7)^{\circ}$ \\
\hline Root/shoot ratio & $1.35 \pm 0.1 .0(15)$ & $4.73 \pm 0.27(7) \cdots$ \\
\hline \multicolumn{3}{|l|}{ Underwater PAR } \\
\hline mol photons $n$ & $2(362)$ & 15.44 \\
\hline
\end{tabular}
shoot height and blade width were completed monthly from May to October 1997. At each sampling date, 1 core sample from each plot was collected with a $9 \mathrm{~cm}$ diameter corer driven about $20 \mathrm{~cm}$ into the sediment. To assess the core size effect on shoot density and biomass, we compared shoot density and biomass on a $\mathrm{m}^{2}$ basis estimated from samples collected by $15 \mathrm{~cm}$ diameter and $9 \mathrm{~cm}$ diameter corers. There were no significant differences in estimated shoot density and biomass between big and small core samples. Therefore, a $9 \mathrm{~cm}$ diameter corer was used to minimize destruction in experimental plots. Samples were thoroughly cleaned of epiphytes and sediments, separated into leaf (blade and sheath), rhizome (vertical and horizontal) and root tissues, and dried at $60^{\circ} \mathrm{C}$ to a constant 


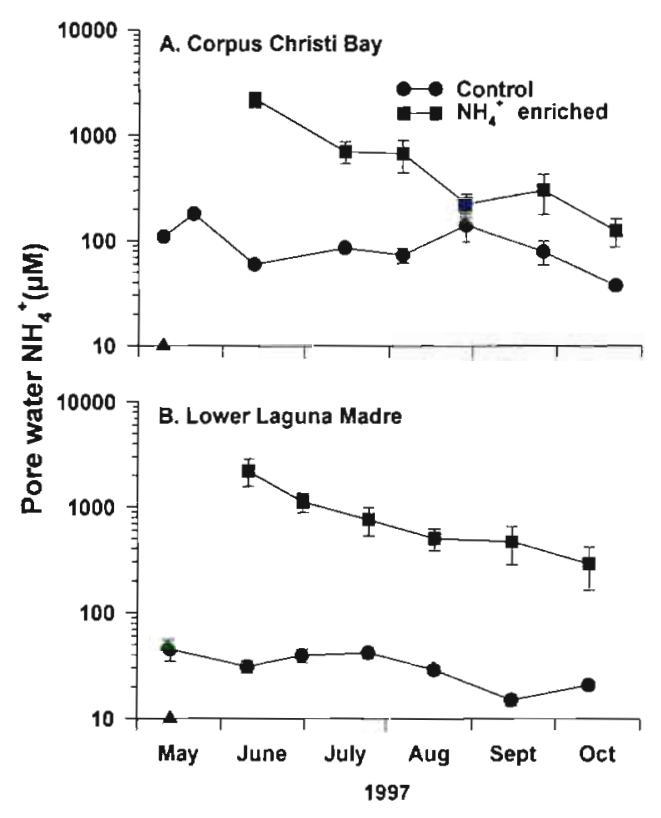

Fig. 2. Sediment pore water $\mathrm{NH}_{4}{ }^{+}$concentrations in control and $\mathrm{NH}_{4}{ }^{+}$enriched seagrass plots in (A) Corpus Christi Bay and (B) lower Laguna Madre between May and October 1997. Triangle on the $x$-axis denotes the date of fertilizer additions. Values are means $\pm S E(n=3)$

weight. Samples were weighed and biomass was converted to an areal estimate ( $g$ dry $w \mathrm{t}^{-2}$ ). Shoot density was estimated by counting the number of shoots inside the core. Shoot height was estimated by measuring the longest leaf length. Blade width was measured to the nearest $0.5 \mathrm{~mm}$ using the mature green leaves in cores collected for biomass.

Leaf production rates were measured using a modified blade marking technique (Zieman 1974, Kentula \& McIntire 1986). Five randomly chosen shoots from each plot were marked just above the bundle sheath with a hypodermic needle and then harvested after a period of 3 to $4 \mathrm{wk}$. Leaf material was separated into leaf tissue produced before and after marking and dried at $60^{\circ} \mathrm{C}$ to a constant weight. The leaf production rate per shoot was determined by dividing the dry weight of new leaf tissue produced after marking by the number of days since marking. Areal production rates were obtained by multiplying the average leaf production per shoot in a given plot by its corresponding shoot density.

Statistics. All values are reported as means \pm 1 standard error (SE). Statistical analyses were performed on a microcomputer using a general linear procedure (SAS Institute 1989). Data were tested for normality and homo- geneity of variance to meet the assumptions of parametric statistics, and assumptions were satisfied for all data tested. Differences in sediment nutrients, shoot density, shoot height, blade width and biomass among sampling time and between treatments were tested for significance using a 2-way ANOVA, with time as a block. When a significant difference among variables was observed, the means were analyzed by a Tukey multiple comparison test to determine where the significant differences occurred among variables.

\section{RESULTS}

\section{Sediment nutrients}

Pore water $\mathrm{NH}_{4}{ }^{+}$concentrations in controi piots at CCB (ca $100 \mu \mathrm{M} \mathrm{NH}_{4}{ }^{+}$) were significantly higher than at LLM (ca $30 \mu \mathrm{M} \mathrm{NH}_{4}{ }^{+}$) over the 6 mo experimental period $(p<0.001)$. During the first month following $\mathrm{NH}_{4}{ }^{+}$enrichment, the concentrations of sediment pore water $\mathrm{NH}_{4}{ }^{+}$increased to $2000 \mu \mathrm{M} \mathrm{NH}_{4}{ }^{+}$at both study sites. By the end of the experiment, 5 mo after $\mathrm{NH}_{4}{ }^{+}$ addition, it declined to about $200 \mu \mathrm{M}$, which was still significantly higher than control plots (Fig. 2).

Since pore water $\mathrm{NO}_{3}{ }^{-}+\mathrm{NO}_{2}{ }^{-}$and $\mathrm{PO}_{4}{ }^{3-}$ concentrations did not exhibit significant seasonal trends, average values throughout the experiment are presented in Table 2. There were no significant differences in pore water $\mathrm{NO}_{3}{ }^{-}+\mathrm{NO}_{2}{ }^{-}$concentrations between study sites $(p=0.66)$ and between $\mathrm{NH}_{4}{ }^{+}$enriched and control plots $(p=0.48$ and $p=0.91$ at CCB and LLM, respectively). Pore water $\mathrm{PO}_{4}{ }^{3-}$ concentration in control plots at CCB (ca $24 \mu \mathrm{MPO}_{4}{ }^{3}{ }^{-}$) was significantly higher than at LLM (ca $15 \mu \mathrm{M} \mathrm{PO}_{4}{ }^{3-} ; \mathrm{p}<0.001$ ). However, the pore water $\mathrm{PO}_{4}{ }^{3-}$ concentrations were not significantly different between $\mathrm{NH}_{4}{ }^{+}$enriched and control plots at both CCB $(p=0.94)$ and LLM $(p=0.79$; Table 2$)$.

\section{Shoot density and leaf morphology}

The average shoot density in control plots at LLM (ca $2000 \mathrm{~m}^{-2}$ ) was significantly higher than at CCB (ca $1700 \mathrm{~m}^{-2} ; \mathrm{p}<0.001$ ). Shoot densities at $\mathrm{CCB}$ ranged

Table 2. Average sediment pore water $\mathrm{NO}_{3}{ }^{-}+\mathrm{NO}_{2}{ }^{-}$and $\mathrm{PO}_{4}{ }^{3-}$ concentrations in control and $\mathrm{NH}_{4}{ }^{+}$enriched seagrass plots in Corpus Christi Bay (CCB) and lower Laguna Madre (LIM). Values are means $\pm \mathrm{SE}(\mathrm{n}=6)$

\begin{tabular}{|c|c|c|c|c|}
\hline & \multicolumn{2}{|c|}{$\mathrm{CCB}$} & \multicolumn{2}{|c|}{ LLLM } \\
\hline & Control & Fertilized & Control & Fertilized \\
\hline $\mathrm{NO}_{3}^{-}+\mathrm{NO}_{2}^{-}(\mu \mathrm{M})$ & $3.42 \pm 0.38$ & $3.05 \pm 0.24$ & $3.07 \pm 0.23$ & $3.01 \pm 0.24$ \\
\hline $\mathrm{PO}_{4}^{3-}(\mu \mathrm{M})$ & $23.80 \pm 3.71$ & $24.20 \pm 3.54$ & $15.08 \pm 2.25$ & $15.48 \pm 1.86$ \\
\hline
\end{tabular}


from $1200 \mathrm{~m}^{-2}$ in July to $2100 \mathrm{~m}^{-2}$ in August and did not change as a result of sediment $\mathrm{NH}_{4}{ }^{+}$enrichment (Fig. 3A). In LLM, shoot densities in the enriched plots also did not increase relative to controls during the first 4 mo following $\mathrm{NH}_{4}{ }^{+}$enrichment, but were significantly higher in the enriched plots by October, 5 mo after fertilization ( $p=0.022$; Fig. 3B).

In control plots, shoot height was significantly higher at CCB than at LLM $(p<0.001)$. Sediment $\mathrm{NH}_{4}{ }^{+}$enrichment had no significant effect on shoot height at CCB $(p=0.226)$. Shoot height at CCB showed a significant seasonal trend ( $p<0.001$ ); values ranged from $30.3 \mathrm{~cm}$ in May to $49.5 \mathrm{~cm}$ in August (Fig. $3 \mathrm{C}$ ). In contrast, shoot height at LLM significantly increased as a result of sediment $\mathrm{NH}_{4}{ }^{+}$enrichment $(p<0.001)$, increasing continuously in enriched plots from $17.7 \mathrm{~cm}$ in May to a maximum of $34.3 \mathrm{~cm}$ in September (Fig. 3D). Shoot height in control plots at LLM remained at ca $18 \mathrm{~cm}$ throughout the experiment.

Average blade widths in control plots at $\mathrm{CCB}(6.3 \mathrm{~mm})$ were significantly higher than at LLM $\left(5.2 \mathrm{~mm}_{i} \mathrm{p}<0.001\right)$. At CCB, blade width in control plots ranged from $5.9 \mathrm{~mm}$ in June to $6.6 \mathrm{~mm}$ in October. There was no significant difference in blade width in enriched plots relative to controls (Fig. 3E). In contrast, blade width at LLM increased significantly relative to controls as a result of $\mathrm{NH}_{4}{ }^{+}$enrichment ( $p<0.001$; Fig. 3F).

\section{Leaf production and plant biomass}

Leaf production rates in control plots at $\mathrm{CCB}(7.35 \mathrm{~g}$ dry wt $\mathrm{m}^{-2} \mathrm{~d}^{-1}$ ) were significantly higher than those at LLM $\left(2.50 \mathrm{~g}\right.$ dry $\left.w \mathrm{~m}^{-2} \mathrm{~d}^{-1} ; \mathrm{p}<0.001\right)$. The rate of leaf production at $\mathrm{CCB}$ was about 2 -fold higher in fertilized plots relative to controls during the first month following $\mathrm{NH}_{4}{ }^{+}$enrichment, although there were no significant differences between fertilized and control plots during subsequent months ( $p=0.109$; Fig. 4 ). Leaf production rates in control plots at $\mathrm{CCB}$ showed a strong seasonal trend ranging from $4.86 \mathrm{~g}$ dry $\mathrm{wt} \mathrm{m}^{-2} \mathrm{~d}^{-1}$ in June to $9.37 \mathrm{~g}$ dry wt m${ }^{-2} \mathrm{~d}^{-1}$ in August. Sediment $\mathrm{NH}_{4}{ }^{+}$ enrichment significantly stimulated leaf production at LLM ( $p<0.001$; Fig. 4). The average leaf production rate in control plots at LLM was $2.50 \mathrm{~g}$ dry $\mathrm{wt} \mathrm{m}^{-2} \mathrm{~d}^{-1}$ and $8.21 \mathrm{~g}$ dry $w \mathrm{w} \mathrm{m}^{-2} \mathrm{~d}^{-1}$ in fertilized plots.

Average leaf biomass in control plots at CCB $(281 \mathrm{~g}$ dry $w \mathrm{t} \mathrm{m}^{-2}$ ) was significantly higher than that at LLM (163 g dry wt $\mathrm{m}^{-2} ; \mathrm{p}<0.001$; Fig. 5). In contrast, average total and rhizome biomass at LLM (889 and $663 \mathrm{~g}$
Corpus Christi Bay
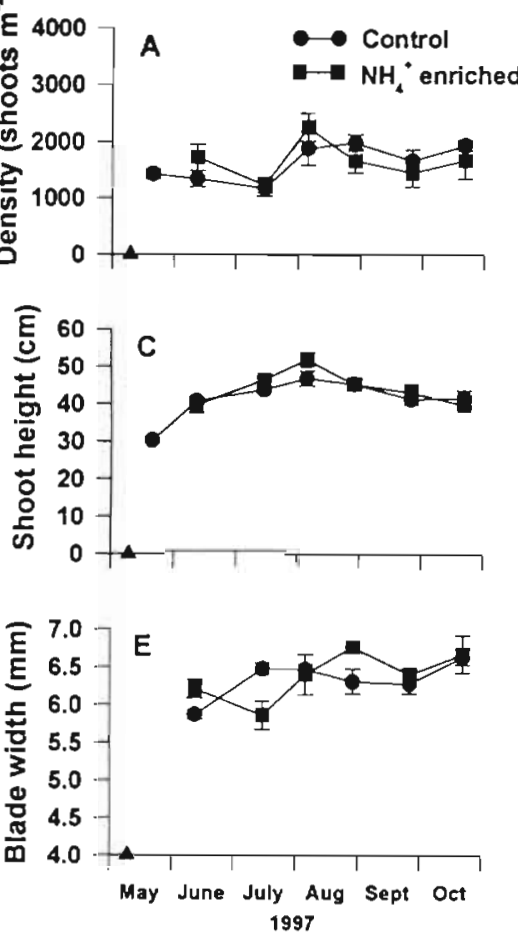

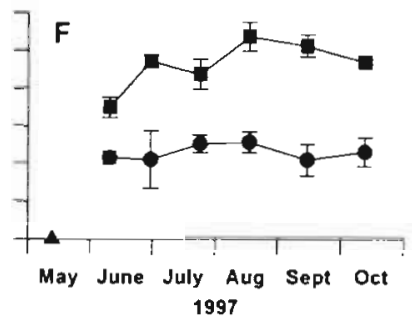

Lower Laguna Madre

B
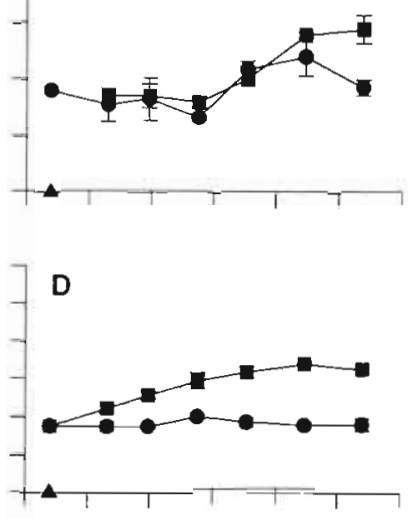

1997
Fig. 3. Thalassia testudinum. $(A, B)$ Shoot density, $(C, D)$ shoot height and $(\mathrm{E}, \mathrm{F})$ blade width in control and sediment $\mathrm{NH}_{4}{ }^{+}$enriched plots at Corpus Christi Bay and lower Laguna Madre between May and October 1997. riangle on the $x$-axis denotes the date of fertilizer additions. Values are means $\pm \operatorname{SE}(n=3)$

dry wt $\mathrm{m}^{-2}$, respectively) were significantly higher than those at CCB $\left(712\right.$ and $358 \mathrm{~g}$ dry wt $\mathrm{m}^{-2}$, respectively; $\mathrm{p}<0.001$ ). Root biomass did not differ significantly between study sites $(p=0.092)$.

There was no significant effect of $\mathrm{NH}_{4}{ }^{+}$enrichment on total biomass as well as the biomass of different tissues at $C C B$ ( $p>0.05$; Fig. 5). However, leaf biomass at the LLM site significantly increased as a result of sediment $\mathrm{NH}_{4}{ }^{+}$enrichment $(\mathrm{p}<0.001)$. Leaf biomass in control plots remained at a weight of about $150 \mathrm{~g}$ dry wt $\mathrm{m}^{-2}$ throughout the experiment, while continuously increasing from $143 \mathrm{~g}$ dry wt $\mathrm{m}^{-2}$ in May to $468 \mathrm{~g}$ dry wt $\mathrm{m}^{-2}$ in September in fertilized plots (Fig. 5). Root and total biomass at LLM did not change during the first 3 mo following $\mathrm{NH}_{4}{ }^{+}$enrichment, although a significant increase was observed during subsequent months $(p=0.013$, root and $p<0.001$, total biomass; Fig. 5). Sediment $\mathrm{NH}_{4}{ }^{+}$enrichment had no significant effect on rhizome biomass at LLM $(p=0.54)$.

Average below-above-ground biomass ratio in control plots at LLM (4.66) was significantly higher than that at $\operatorname{CCB}(1.63 ; p<0.001)$. About $60 \%$ of total biomass was apportioned below ground in control plots at CCB. At LLM, about $82 \%$ of total biomass corre- 


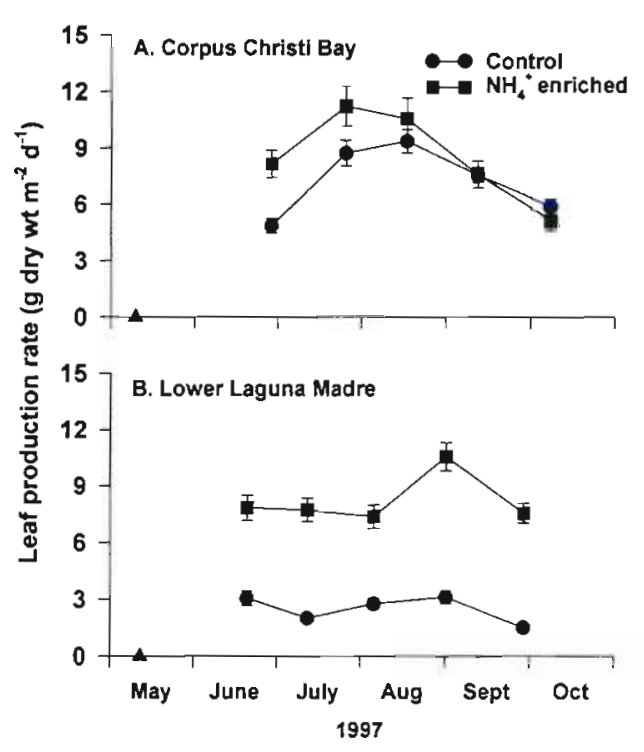

Fig. 4. Thalassia testudinum. Leaf production rate ( $g$ dry wt $\mathrm{m}^{-2} \mathrm{~d}^{-1}$ ) in control and sediment $\mathrm{NH}_{4}{ }^{+}$enriched plots at (A) Corpus Christi Bay and (B) lower Laguna Madre between May and October 1997. Triangle on the $x$-axis denotes the date of fertilizer additions. Values are means $\pm \operatorname{SE}(n=3)$

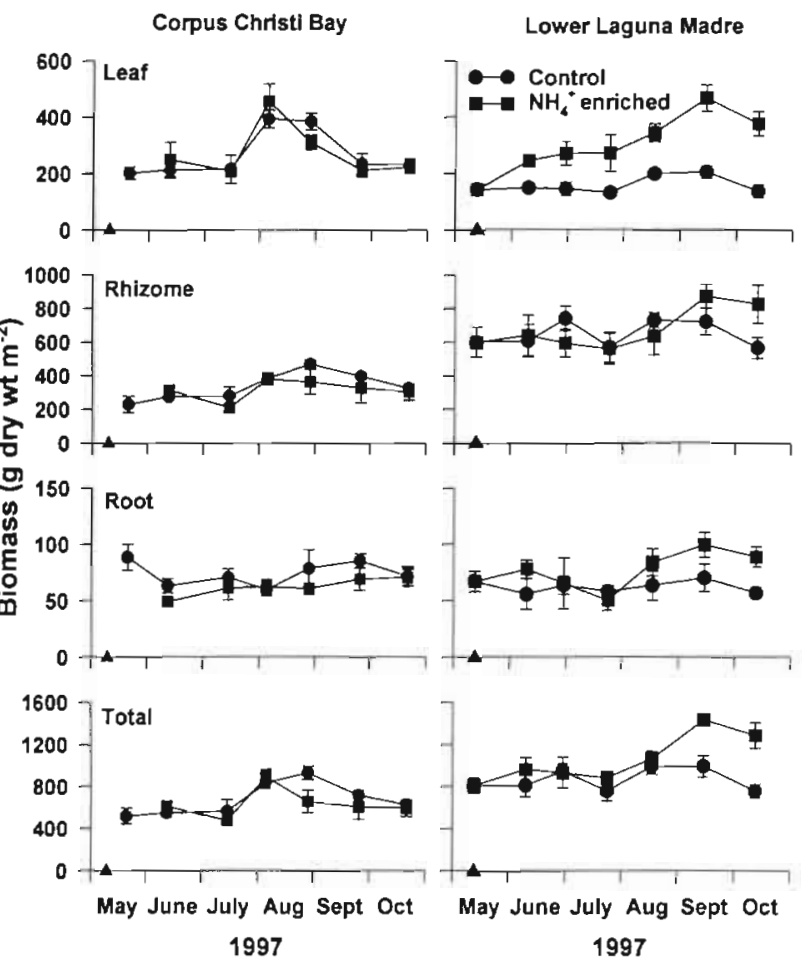

Fig. 5. Thalassia testudinum. Biomass of total and different plant components in control and sediment $\mathrm{NH}_{4}{ }^{*}$ enriched plots at Corpus Christi Bay and lower Laguna Madre between May and October 1997. Triangle on the $x$-axis denotes the date of fertilizer additions. Values are means $\pm S E(n=3)$

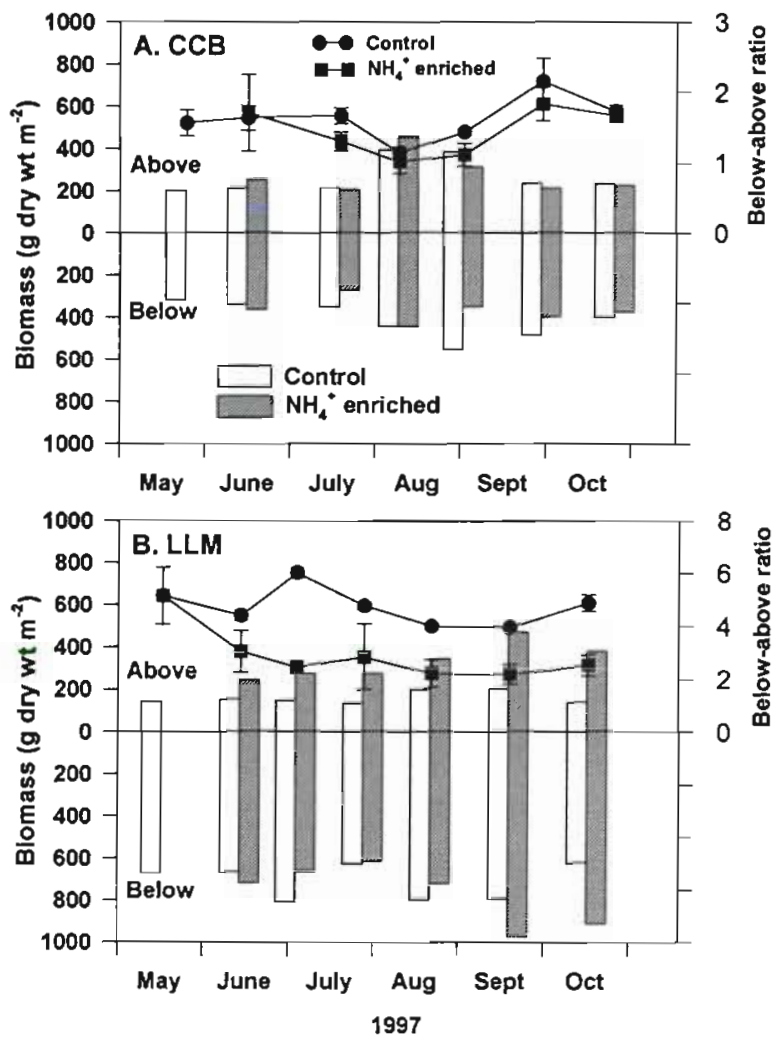

Fig. 6. Thalassia testudinum. Above-and below-ground biomass and below-above-ground biomass ratios in control and sediment $\mathrm{NH}_{4}{ }^{+}$enriched plots at (A) Corpus Christi Bay (CCB) and (B) lower Laguna Madre (LLM) between May and October 1997

sponded to below-ground biomass in control plots and $72 \%$ of total biomass in fertilized plots. At CCB, there was no significant effect of $\mathrm{NH}_{4}{ }^{+}$enrichment on belowabove-ground biomass ratio ( $p=0.133$; Fig. 6$)$. However, below-above-ground biomass ratio in enriched plots (2.53) at LLM was significantly lower than that in control plots (4.66; $p<0.001$; Fig. 6).

\section{DISCUSSION}

\section{$\mathrm{N}$ availability for seagrass growth}

Increased $\mathrm{N}$ availability as a result of $\mathrm{NH}_{4}{ }^{+}$fertilization had little effect on seagrass growth and leaf morphology at site CCB, which is characterized by having a higher ambient sediment pore water $\mathrm{NH}_{4}{ }^{+}$level (ca $100 \mu \mathrm{M}$ ). Despite a 20 -fold increase in $\mathrm{N}$ availability as a result of the fertilization, no differences in shoot density, shoot height, blade width and biomass were observed between control and fertilized plots. A similar lack of change in leaf biomass and shoot density in response to enrichment was reported by Bulthuis \& 
Woelkerling (1981) in a Heterozostera tasmanica bed. They hypothesized that the high ambient pore water $\mathrm{NH}_{4}{ }^{+}$level in their study area (200 to $1700 \mu \mathrm{M} \mathrm{NH}{ }_{4}^{+}$) provided an adequate reserve of $\mathrm{N}$ for seagrass growth. Zostera marina in Great Harbor, Massachusetts, showed little response in leaf production and biomass to sediment $\mathrm{NH}_{4}{ }^{+}$manipulation, which resulted in concentrations of 100 to $1000 \mathrm{MM} \mathrm{NH}_{4}{ }^{+}$(Dennison et al. 1987). Therefore, sediment $\mathrm{NH}_{4}{ }^{+}$availability was considered to be in excess of seagrass $\mathrm{N}$ demand.

Short (1983) and Dennison et al. (1987) reported significantly smaller eelgrass leaf size and lower leaf production rates when sediment pore water $\mathrm{NH}_{4}{ }^{+}$concentrations dropped below ca $100 \mu \mathrm{M}$, the suggested threshold concentration for $\mathrm{N}$ limitation for Zostera marina. The proposed threshold value of $1.00 \mu \mathrm{M}$ is similar to saturation concentrations reported for $Z$. marina $\mathrm{NH}_{4}{ }^{+}$uptake by root tissues (Iizumi \& Hattori 1982, Thursby \& Harlin 1982). In the present study, changes in sediment $N$ availability from 100 to $2000 \mu \mathrm{M} \mathrm{NH}_{4}{ }^{+}$had no significant effect on shoot density, leaf morphology and biomass of Thalassia testudinum. The lack of response to sediment $\mathrm{NH}_{4}{ }^{+}$ enrichment by $T$. testudinum plants at CCB suggests that ambient pore water $\mathrm{NH}_{4}{ }^{+}$concentrations of $100 \mu \mathrm{M}$ may provide an adequate pool of inorganic $\mathrm{N}$ for $T$. testudinum growth. This suggestion is consistent with reports for various seagrass species (Table 3). Seagrass growth has been limited at the range of ambient pore water $\mathrm{NH}_{4}{ }^{+}$concentration from 7.4 to $137 \mu \mathrm{M}$, while seagrasses growing in the range of 100 to
$1000 \mu \mathrm{M}$ have been demonstrated to be provided with sufficient $\mathrm{N}$ for growth.

Although sediment $\mathrm{NH}_{4}{ }^{+}$concentrations in seagrass beds are indicative of $\mathrm{N}$ limitation of seagrass growth, turnover rates of the sediment $\mathrm{NH}_{4}{ }^{+}$pool and the regeneration of sediment $\mathrm{NH}_{4}{ }^{+}$are also important factors that determine the degree of $\mathrm{N}$ limitation. Sediment $\mathrm{NH}_{4}{ }^{+}$pools in seagrass beds have been reported to have rapid turnover rates ranging from 0.3 to $6 \mathrm{~d}$ (Capone 1982, Moriarty et al. 1985, Boon et al. 1986, Lee \& Dunton 1999b). Bacterial $\mathrm{N}_{2}$ fixation provides substantial inputs of $\mathrm{N}$ in seagrass beds (Capone \& Taylor 1980, Capone 1982, Moriarty \& O'Donohue 1993). Additionally, bacterial sulfate reduction in sediments is important in terms of the regeneration of sediment nutrients (Hines \& Lyons 1982, Holmer \& Nielsen 1997). Since $\mathrm{NH}_{4}{ }^{+}$regeneration rates vary spatially and temporally (Jørgensen 1977. Moriarty \& O'Donohue 1993), the sediment $\mathrm{NH}_{4}{ }^{+}$pool size for $\mathrm{N}$ limitation of seagrass growth should also vary spatially and temporally.

Nitrogen availability in muddy sediments is usually higher than that in sandy sediments (Short 1983, 1987). In the present study, however, the sandy sediments at the CCB site were characterized by higher $\mathrm{N}$ availability. Processes of $\mathrm{N}$ input into sediments of seagrass meadows are $\mathrm{N}$ fixation in the rhizosphere and phyllosphere (Capone et al. 1979, Capone \& Taylor 1980, Capone 1982, Moriarty \& O'Donohue 1993), settlement of particulate organic matter (Kenworthy \& Thayer 1984, Cooper 1989) and $N$ uptake from the water col-

Table 3. Species-specific response to nitrogen fertilization and nitrogen limitation reported in in situ seagrass beds during growing season. (+) Increases from controls due to sediment nitrogen fertilization, (ns) no significant change, (L) nitrogen limitation for seagrass growth and (N) no nitrogen limitation

\begin{tabular}{|c|c|c|c|c|c|c|c|c|c|}
\hline \multirow[t]{2}{*}{ Species } & \multirow{2}{*}{$\begin{array}{c}\text { Ambient } \\
\text { pore water } \\
\mathrm{NH}_{4}^{+}(\mu \mathrm{M})\end{array}$} & \multicolumn{5}{|c|}{ Responses to $\mathrm{N}$ fertilization } & \multirow{2}{*}{$\stackrel{N}{\text { limitation }}$} & \multirow[t]{2}{*}{ Location } & \multirow[t]{2}{*}{ Source } \\
\hline & & $\begin{array}{c}\text { Leaf } \\
\text { biomass }\end{array}$ & $\begin{array}{l}\text { Shoot } \\
\text { height }\end{array}$ & $\begin{array}{l}\text { Shoot } \\
\text { density }\end{array}$ & $\begin{array}{l}\text { Growth } \\
\text { rate }\end{array}$ & $\begin{array}{l}\text { Tissue N } \\
\text { content }\end{array}$ & & & \\
\hline $\begin{array}{l}\text { Heterozostera } \\
\text { tasmanica }\end{array}$ & $11-19$ & + & + & + & & + & $\mathrm{L}$ & $\begin{array}{l}\text { Port Phillip Bay, } \\
\text { Australia }\end{array}$ & $\begin{array}{l}\text { Bulthuis et al. } \\
\text { (1992) }\end{array}$ \\
\hline $\begin{array}{l}\text { Halodule } \\
\text { uninervis }\end{array}$ & 7.4 & + & + & + & + & + & L & $\begin{array}{l}\text { Moreton Bay, } \\
\text { Australia }\end{array}$ & $\begin{array}{l}\text { Udy \& Dennison } \\
\text { (1997) }\end{array}$ \\
\hline $\begin{array}{l}\text { Zostera } \\
\text { capricorni }\end{array}$ & 7.4 & ns & ns & ns & ns & + & $\mathrm{L}$ & $\begin{array}{l}\text { Moreton Bay, } \\
\text { Australia }\end{array}$ & $\begin{array}{l}\text { Udy \& Dennison } \\
\text { (1997) }\end{array}$ \\
\hline $\begin{array}{l}\text { Zostera } \\
\text { marina }\end{array}$ & $30-137$ & & & & + & & $\mathrm{L}$ & $\begin{array}{l}\text { Puget Sound, WA, } \\
\text { USA }\end{array}$ & $\begin{array}{l}\text { Williams \& Ruckels - } \\
\text { haus (1993) }\end{array}$ \\
\hline $\begin{array}{l}\text { Thalassia } \\
\text { hemprichii }\end{array}$ & ca 100 & ns & & ns & ns & + & $\mathrm{N}$ & Indonesia & $\begin{array}{l}\text { Erftemeijer et al. } \\
\text { (1994) }\end{array}$ \\
\hline $\begin{array}{l}\text { Zostera } \\
\text { marina }\end{array}$ & ca 400 & ns & & & ns & ns & $N$ & $\begin{array}{l}\text { Chesapeake Bay, } \\
\text { USA }\end{array}$ & $\begin{array}{l}\text { Murray et al. } \\
\text { (1992) }\end{array}$ \\
\hline $\begin{array}{l}\text { Zostera } \\
\text { marina }\end{array}$ & $100-1000$ & ns & & & ns & & $\mathrm{N}$ & $\begin{array}{l}\text { Great Harbor, MA, } \\
\text { USA }\end{array}$ & $\begin{array}{l}\text { Dennison et al. } \\
\text { (1987) }\end{array}$ \\
\hline $\begin{array}{l}\text { Thalassia } \\
\text { testudinum }\end{array}$ & $\begin{array}{c}100 \\
30\end{array}$ & $\begin{array}{c}\text { ns } \\
+\end{array}$ & $\begin{array}{l}\text { ns } \\
+\end{array}$ & $\begin{array}{l}\text { ns } \\
\text { ns }\end{array}$ & $\begin{array}{c}\text { ns } \\
+\end{array}$ & + & $\begin{array}{l}N \\
L\end{array}$ & $\begin{array}{l}\text { CCB, TX, USA } \\
\text { LLM, TX, USA. }\end{array}$ & $\begin{array}{l}\text { Present } \\
\text { study }\end{array}$ \\
\hline
\end{tabular}


umn (Hemminga et al. 1991). There are no available values on $\mathrm{N}$ fixation and sedimentation rates in these study areas, but limited riverine input into LLM (Texas Department of Water Resources 1983) is presumed to be one of the factors responsible for low sediment $\mathrm{N}$ availability in the LLM.

Short (1987) demonstrated that the sediment geochemistry in seagrass beds is important in determining the limiting nutrient to seagrass growth. Seagrasses growing in terrigenous sediments are N-limited, while seagrass growing in biogenic carbonate sediments are often P-limited due to binding of phosphate in the sediments (Short et al. 1990, Pérez et al. 1991, Fourqurean et al. 1992). In the present study, both CCB and LLM sites have terrigenous sediment, and sediment pore water phosphate concentrations at the study sites ( 24 and $15 \mu \mathrm{M}$ at CCB and LLM, respectively) were much higher than those reported in P-limited seagrass beds (0.2 to $2.7 \mu$ M; Short et al. 1990, Fourqurean et al. 1992, Agawin et al. 1996). If Thalassia testudinum at LLM is limited by $P$ or both $N$ and $P$, the growth at LLM should not increase as a result of $\mathrm{N}$ fertilization. However, in this study, T. testudinum growth and plant size at LLM increased significantly after sediment $\mathrm{NH}_{4}{ }^{+}$enrichment. Therefore, low growth rates and short-narrow leaf morphology at LLM must be the result of low N availability at this site. Lower tissue $N$ content in LLM than CCB also suggested $\mathrm{N}$ limitation in LLM (Lee \& Dunton 1999a). T. testudinum growing in tropical environments and carbonate sediments, however, are likely to be $\mathrm{P}$-limited rather than $\mathrm{N}$-limited.

\section{Plant responses to sediment $\mathrm{NH}_{4}{ }^{+}$enrichment}

Ambient sediment pore water $\mathrm{NH}_{4}{ }^{+}$concentration at LLM (ca $30 \mu \mathrm{M}$ ) was approximately one-third that at $\mathrm{CCB}$ (ca $100 \mu \mathrm{M}$ ), and $\mathrm{NH}_{4}{ }^{+}$fertilization significantly increased $\mathrm{N}$ availability. Leaf production rate, leaf morphology and biomass significantly responded to sediment $\mathrm{NH}_{4}{ }^{+}$enrichment at LLM. Short (1983) reported a strong correlation between sediment $\mathrm{NH}_{4}{ }^{+}$availability and leaf morphology for Zostera marina. Plants characterized by short and narrow leaves grew in low sediment $\mathrm{N}$ areas, while plants exhibiting long and wide leaves were found in high sediment $N$ areas. In the present study, Thalassia testudinum plants in LLM (low sediment $\mathrm{NH}_{4}{ }^{+}$) had significantly shorter and narrower leaves than those at $\mathrm{CCB}$ (high sediment $\mathrm{NH}_{4}{ }^{+}$). Shoot length and blade width at LLM increased significantly as a result of sediment $\mathrm{NH}_{4}{ }^{+}$enrichment. The increased leaf size in enriched plots at LLM was equivalent to that at $\mathrm{CCB} 4 \mathrm{mo}$ after the $\mathrm{NH}_{4}{ }_{4}^{+}$enrichment.

Shoot density was significantly higher at the low sediment $\mathrm{NH}_{4}{ }^{+}$site (LLM) than at the high sediment
$\mathrm{NH}_{4}{ }^{+}$site (CCB). Fertilization experiments contradict this relationship, showing the increase of shoot density as a result of sediment $\mathrm{N}$ fertilization at the low sediment $\mathrm{NH}_{4}{ }^{+}$site. Short (1983) noted this contradiction in Zostera marina beds. With an increase in $\mathrm{N}$ supply by the $\mathrm{N}$ fertilization, plants initially respond by producing new shoots. However, plants become larger and self shading occurs after long-term $\mathrm{N}$ enrichment. Higher shoot densities become disadvantageous as shoots compete for light. Therefore, plants at LLM will produce fewer, but larger shoots after long-term $\mathrm{N}$ fertilization.

Increased leaf production rate as a result of N enrichment has been shown to be the most pronounced response of seagrass in a $\mathrm{N}$-limited environment (Bulthuis \& Woelkerling 1981, Agawin et al. 1996, Alcoverro et al. 1997, Udy \& Dennison 1997). At ambient sediment $\mathrm{NH}_{4}{ }^{+}$concentrations, leaf production rates at $\mathrm{CCB}$ were about 3 -fold higher than those at LLM. In fertilized plots at LLM, however, leaf production rates increased significantly to about 3 times that of the control plots. Hence, leaf production rates at LLM after sediment $\mathrm{NH}_{4}{ }^{+}$enrichment were similar to those at CCB. In LLM, increases in leaf production rate, shoot length and blade width in enriched plots to values similar to those observed at $C C B$ suggest that Thalassia testudinum growth in the LLM site is limited by low sediment $\mathrm{N}$ availability, while plants at $\mathrm{CCB}$ are exposed to $\mathrm{N}$-sufficient conditions.

Significant increases in leaf biomass in response to nutrient additions have been reported from various seagrass species (Orth 1977. Bulthuis et al. 1992, Agawin et al. 1996, Udy \& Dennison 1997). In the present study, leaf biomass at LLM increased significantly as a result of sediment $\mathrm{NH}_{4}{ }^{+}$enrichment, although there was little change in below-ground biomass. Similar biomass responses have been reported for Zostera marina (Orth 1977), Halodule uninervis and Zostera capricorni (Udy \& Dennison 1997). These responses are indicative of a stimulating effect of sediment $\mathrm{NH}_{4}{ }^{+}$ enrichment on above-ground biomass. Increased $\mathrm{NH}_{4}{ }^{+}$ assimilation due to sediment $\mathrm{NH}_{4}{ }^{+}$enrichment would require more carbon to incorporate assimilated $\mathrm{NH}_{4}{ }^{+}$ into amino acids (Turpin et al. 1990, Huppe \& Turpin 1994). The increased carbon demand must be supplied by photosynthetic carbon fixation that is conducted in leaf tissues. Consequently, increases in leaf surface area are often associated with enhancement of leaf production rates and biomass to meet the increased carbon demand resulting from increased inorganic $\mathrm{N}$ assimilation during $\mathrm{NH}_{4}{ }^{+}$enrichment.

In contrast, plants under sediment nutrient deficient conditions increase biomass allocation to belowground tissues to expand surface area for nutrient uptake (Gleeson 1993, Vogt et al. 1993). In the present 
study, the below/above-ground biomass ratio at LLM was about 3 -fold higher than that at CCB. This biomass allocation trend agrees with general plant response to sediment nutrient availability. Since below-ground biomass did not respond to short-term $\mathrm{NH}_{4}{ }^{+}$enrichment, the significant decrease in below-above-ground biomass ratios at LLM due to sediment $\mathrm{NH}_{4}{ }^{+}$enrichment occurred as a result of enhanced leaf biomass. Increased carbon allocation to the shoots as a result of $\mathrm{N}$ fertilization and enhancement of below-ground carbon allocation as a result of elevated $\mathrm{CO}_{2}$ concentrations have been reported in terrestrial grass species (Cotrufo \& Gorissen 1997). Therefore, $\mathrm{C}$ and $\mathrm{N}$ availability may have a reverse effect on biomass allocation to above-or below-ground tissues: increasing root biomass at high $\mathrm{C}$ and/or low $\mathrm{N}$ availability and increasing leaf biomass at low $\mathrm{C}$ and/or high $\mathrm{N}$ availability. Changes in plant biomass allocation appear to reflect differences in $\mathrm{N}$ availability as the plant responds to imbalances in the ratio of nutrient versus carbon supplies.

Acknowledgements. We are very grateful to S. Herzka, C. Weilhoefer, H. Miller, J. Kaldy and K. Machalek-Major for their extremely helpful comments. This work would not have been possible without field and lab assistance from S. Schonberg, K. Jackson, J. Kowalski and R. Pritchard. R. Benner, C. Onuf, E. Ingall, and P. Montagna provided helpful comments on earlier versions of this manuscript. This work was supported by the US Army Corps of Engineers award no. 96-9203. Additional salary support was provided by E. J. Lund Fellowship to K.-S.L. This is contribution no. 1134 of the Marine Science Institute, University of Texas at Austin.

\section{LITERATURE CITED}

Agawin NSR, Duarte CM, Fortes MD (1996) Nutrient limitation of Philippine seagrasses (Cape Bolinao, NW Philippines): in situ experimental evidence. Mar Ecol Prog Ser 138:233-243

Alcoverro T, Romero J, Duarte CM, López NI (1997) Spatial and temporal variations in nutrient limitation of seagrass Posidonia oceanica growth in the NW Mediterranean. Mar Ecol Prog Ser 146:155-161

Boon PI, Moriarty DJW, Saffigna PG (1986) Rates of ammonium turnover and the role of amino-acid deamination in seagrass (Zostera capricorni) beds of Moreton Bay, Australia. Mar Biol 91;259-268

Bulthuis DA, Woelkerling WJ (1981) Effects of in situ nitrogen and phosphorus enrichment of the sediments on the seagrass Heterozostera tasmanica (Martens ex Aschers.) den Hartog in Western Port, Victoria, Australia. J Exp Mar Biol Ecol 53:193-207

Bulthuis DA, Axelrad DM, Mickelson MJ (1992) Growth of the seagrass Heterozostera tasmanica limited by nitrogen in Port Phillip Bay, Australia. Mar Ecol Prog Ser 89:269-275

Burkholder JM, Mason KM, Glasgow HB Jr (1992) Water-column nitrate enrichment promotes decline of eelgrass Zostera marina: evidence from seasonal mesocosm experiments. Mar Ecol Prog Ser 81:163-178

Burkholder JM. Glasgow HB Jr, Cooke JE (1994) Comparative effects of water-column nitrate enrichment on eel- grass Zostera marina, shoalgrass Halodule wrightii, and widgeongrass Ruppia maritima. Mar Ecol Prog Ser 105: $121-138$

Capone DG (1982) Nitrogen fixation (acetylene reduction) by rhizosphere sediments of the eelgrass Zostera marina. Mar Ecol Prog Ser 10:67-75

Capone DG, Taylor BF (1980) $\mathrm{N}_{2}$ fixation in the rhizosphere of Thalassia testudinum. Can J Microbiol 26:998-1005

Capone DG, Penhale PA, Oremland RS, Taylor BF (1979) Relationship between productivity and $\mathrm{N}_{2}\left(\mathrm{C}_{2} \mathrm{H}_{2}\right)$ fixation in a Thalassia testudinum community. Limnol Oceanogr $24: 117-125$

Cooper LW (1989) Patterns of carbon isotopic variability in eelgrass, Zostera marina L., from Izembek Lagoon, Alaska. Aquat Bot 34:329-339

Cotrufo MF, Gorissen A (1997) Elevated $\mathrm{CO}_{2}$ enhances below-ground $\mathrm{C}$ allocation in three perennial grass species at different levels of $N$ availability. New Phytol 137: $421-431$

Czerny AB, Dunton KH (1995) The effects of in situ light reduction on the growth of two species of subtropical seagrasses, Thalassia testudinurn and Halodule wrightix. Estuaries 18:418-427

Dennison WC, Aller RC, Alberte R (1987) Sediment ammonium availability and eelgrass (Zostera marina) growth Mar Biol 94:469-477

Dunton KH (1990) Production ecology of Ruppia maritima L. s.l. and Halodule wrightii Aschers. in two subtropical estuaries. J Exp Mar Biol Ecol 143:147-164

Dunton KH (1994) Seasonal growth and biomass of the subtropical seagrass Halodule wrightii in relation to continuous measurements of underwater irradiance. Mar Biol $120: 479-489$

Dunton KH (1996) Photosynthetic production and biomass of the subtropical seagrass Halodule wrightii along an estuarine gradient. Estuaries 19:436-447

Erftemeijer PLA, Stapel J, Smekens MJE, Drossaert WME (1994) The limited effect of in situ phosphorus and nitrogen additions to seagrass beds on carbonate and terrigenous sediments in South Sulawesi, Indonesia. J Exp Mar Biol Ecol 182:123-140

Fourqurean JW, Zieman JC, Powell GVN (1992) Relationships between porewater nutrients and seagrasses in a subtropical carbonate environment. Mar Biol 114:57-65

Giesen WBJT, van Katwijk MM, den Hartog C (1990) Eelgrass condition and turbidity in the Dutch Wadden Sea. Aquat Bot 37:71-85

Gleeson SK (1993) Optimization of tissue nitrogen and rootshoot allocation. Ann Bot 71:23-31

Harlin MM, Thorne-Miller B (1.981) Nutrient enrichment of seagrass beds in a Rhode Island coastal lagoon. Mar Biol 65:221-229

Hemminga MA, Harrison PG, van Lent F (1991) The balance of nutrient losses and gains in seagrass meadows. Mar Ecol Prog Ser 71:85-96

Herzka SZ, Dunton KH (1997) Seasonal photosynthetic patterns of the seagrass Thalassia testudinum in the western Gulf of Mexico. Mar Ecol Prog Ser 152:103-117

Herzka SZ, Dunton KH (1998) Light and carbon balance in the seagrass Thalassia testudinum: evaluation of current production models. Mar Biol 132:711-721

Hines ME, Lyons WB (1982) Biogeochemistry of nearshore Bermuda sediments. I. Sulfate reduction rates and nutrient generation. Mar Ecol Prog Ser 8:87-94

Holmer M, Nielsen SL (1997) Sediment sulfur dynamics related to biomass-density patterns in Zostera marina (eelgrass) beds. Mar Ecol Prog Ser 146:163-171 
Huppe HC, Turpin DH (1994) Interaction of carbon and nitrogen metabolism in plant and algal cells. Annu Rev Plant Physiol Plant Mol Biol 45:577-607

Iizumi H, Hattori A (1982) Growth and organic production of eelgrass (Zostera marina L.) in temperate waters of the Pacific coast of Japan. III. The kinetics of nitrogen uptake. Aquat Bot 12:245-256

Iizumi H, Hattori A, McRoy CP (1982) Ammonium regeneration and assimilation in eelgrass (Zostera marina) beds. Mar Biol 66:59-65

Jørgensen BB (1977) The sulfur cycle of a coastal marine sediment (Limfjorden, Denmark). Limnol Oceanogr 22: $814-832$

Jørgensen BB (1982) Mineralization of organic matter in the sea-bed-the role of sulphate reduction. Nature 296: 643-645

Kaldy JE (1997) Production dynamics, reproductive ecology and demography of Thalassia testudinum (turtle grass) from the lower Laguna Madre, Texas. Doctoral dissertation, The University of Texas at Austin

Kentula ME, McIntire CD (1986) The autecology and production dynamics of eelgrass (Zostera marina L.) in Netarts Bay, Oregon. Estuaries 9:188-199

Kenworthy WJ, Thayer GW (1984) Production and decomposition of the roots and rhizome of seagrasses, Zostera marina and Thalassia testudinum, in temperate and subtropical marine ecosystems. Bull Mar Sci 33:364--379

Kenworthy WJ, Zieman JC, Thayer GW (1982) Evidence for the influence of seagrasses on the benthic nitrogen cycle in a coastal plain estuary near Beaufort, North Carolina (USA). Oecologia 54:152-158

Lee KS, Dunton KH (1996) Production and carbon reserve dynamics of the seagrass Thalassia testudinum in Corpus Christi Bay, Texas, USA. Mar Ecol Prog Ser 143:201-210

Lee KS, Dunton KH (1997) Effects of in situ light reduction on the maintenance, growth and partitioning of carbon resources in Thalassia testudinum. J Exp Mar Biol Ecol 210:53-73

Lee KS, Dunton KH (1999a) Influence of sediment nitrogen availability on carbon and nitrogen dynamics in the seagrass Thalassia testudinum. Mar Biol 134:217-226

Lee KS, Dunton KH (1999b) Inorganic nitrogen acquisition in the seagrass Thalassia testudinum: development of a whole-plant nitrogen budget. Limnol Oceanogr 44: $1204-1215$

McRoy CP, McMillan C (1977) Production ecology and physiology of seagrasses. In: McRoy CP, Helfferich C (eds) Seagrass ecosystems: a scientific perspective. Dekker, New York, p 53-81

Moriarty DJW, O'Donohue MJ (1993) Nitrogen fixation in seagrass communities during summer in the Gulf of Carpentaria, Australia. Aust J Mar Freshw Res 44:117-125

Moriarty DJW, Boon PI, Hansen J, Hunt WG, Pointer IR, Pollard PC, Skyring GW, White DC (1985) Microbial biomass and productivity in seagrass beds. Geomicrobiol J 4:21-51

Murray L, Dennison WC, Kemp WM (1992) Nitrogen versus phosphorus limitation for growth of an estuarine population of eelgrass (Zostera marina). Aquat Bot 44:83-100

Orth RJ (1977) Effect of nutrient enrichment on growth of the eelgrass Zostera manina in the Chesapeake Bay, Virginia. USA. Mar Biol 44:187-194

Orth RJ, Moore KA (1983) Chesapeake Bay: an unprecedented decline in submerged aquatic vegetation. Science 222:51-53

Parsons TR, Maita Y, Lalli CM (1984) A manual of chemical and biological methods for seawater analysis. Pergamon Press, New York
Pérez M, Romero J, Durate CM, Sand-Jensen K (1991) Phosphorus limitation of Cymodocea nodosa growth. Mar Biol 109:129-133

Quammen ML, Onuf CP (1993) Laguna Madre: seagrass changes continue decades after salinity reduction. Estuaries 16:302-310

Romero J, PJrez M, Mateo MA, Sala E (1994) The belowground organs of the Mediterranean seagrass Posidonia oceanica as a biogeochemical sink. Aquat Bot 47:13-19

SAS Institute Inc (1989) SAS/STAT guide for personal computers, version 6,4 th edn. SAS Institute, Cary, NC

Short FT (1983) The seagrass, Zostera marina L.: plant morphology and bed structure in relation to sediment ammonium in Izembek Lagoon, Alaska. Aquat Bot 16:149-161

Short FT (1987) Effects of sediment nutrients on seagrasses: literature review and mesocosm experiment. Aquat Bot 27:41-57

Short FT, McRoy CP (1984) Nitrogen uptake by leaves and roots of the seagrass Zostera marina L. Bot Mar 27:547-555

Short FT, Dennison WC, Capone DG (1990) Phosphorus-limited growth of the tropical seagrass Syringodium filiforme in carbonate sediments. Mar Ecol Prog Ser 62:169-174

Silberstein K, Chiffings AW, McComb AJ (1986) The loss of seagrass in Cockburn Sound, Western Australia. III. The effect of epiphytes on productivity of Posidonia australis Hook. F. Aquat Bot 24:355-371

Stapel J, Hemminga MA (1997) Nutrient resorption from seagrass leaves. Mar Biol 128:197-206

Stapel J, Aarts TL, van Duynhoven BHM, de Groot JD, van den Hoogen PHV, Hemminga MA (1996) Nutrient uptake by leaves and roots of the seagrass Thalassia hemprichii in the Spermonde Archipelago, Indonesia. Mar Ecol Prog Ser 134:195-206

Terrados J, Williams SL (1997) Leaf versus root nitrogen uptake by the surfgrass Phyllospadix torreyi. Mar Ecol Prog Ser 149:267-277

Texas Department of Water Resources (1983) Laguna Madre Estuary: a study of the influence of freshwater inflows. LP. 182, Texas Department of Water Resources, Austin, TX

Thursby GB, Harlin MM (1982) Leaf-root interaction in the uptake of ammonium by Zostera marina. Mar Biol 72: 109-112

Tomasko DA, Lapointe BE (1991) Productivity and biomass of Thalassia testudinum as related to water column nutrient availability and epiphyte level: field observations and experimental studies. Mar Ecol Prog Ser 75:9-17

Turpin DA, Botha FC, Smith RG, Feil R, Horsey AK, Vanlerberghe GC (1990) Regulation of carbon partitioning to respiration during dark ammonium assimilation by the green alga Selenastrum minutum. Plant Physiol 93:166-175

Udy JW, Dennison WC (1997) Growth and physiological responses of three seagrass species to elevated sediment nutrients in Moreton Bay, Australia. J Exp Mar Biol Ecol 217:253-277

Vogt KA, Publicover DA, Bloomfield J, Pérez JM, Vogt DJ, Silver WL (1993) Belowground responses as indicators of environmental change. Environ Exp Bot 33:189--205

Williams SL, Ruckelshaus MH (1993) Effects of nitrogen availability and herbivory on eelgrass (Zostera marina) and epiphytes. Ecology 74:904-918

Zieman JC (1974) Methods for the study of the growth and production of turtle grass, Thalassia testudinum König. Aquaculture 4:139-143

Zimmerman RC, Smith RD, Alberte RS (1987) Is growth of eelgrass nitrogen limited? A numerical simulation of the effects of light and nitrogen on the growth dynamics of Zostera marina. Mar Ecol Prog Ser 41:167-176 